formę uporządkowanej monografii. Wpisanie tych materiałów w nurt książki, umiejętne uporządkowanie uszczegółowionych opisów omawianych subdyscyplin sprawia, że nie jest to przypadkowe zestawienie czy zlepek tekstów „,na temat”, ale bogaty materiał poznawczy. Praca jest napisana starannie, językiem przystępnym. Mogę zatem stwierdzić, że autorka osiągnęła cel określony we wstępie do pracy. Przez treść pracy przebija świadomość autorki co do podstawowego problemu badawczego, jaki podjęła.

Pragnę podkreślić ogromną, niekwestionowaną wartość pracowicie zgromadzonej przez autorkę bibliografii źródłowej oraz przedmiotowej. Praca prof. Heleny Słotwińskiej jest niezwykle cennym dokonaniem dla pedagogiki religijnej i katechetyki. Jest ona jednocześnie ważnym źródłem informacji dla pracowników naukowych, podejmujących problematykę pedagogiki religii i katechetyki, a zwłaszcza studentów w trudzie inicjacji w niełatwą przecież problematykę. Praca zawiera wiele cennego materiału poznawczego, także dla innych odbiorców, zwłaszcza w pogłębieniu spojrzenia na trud przekazu wiary w dziele wychowania inspirowanego Objawieniem oraz chrześcijańskim dziedzictwem. Należy także podkreślić staranne opracowanie szaty graficznej książki, od strony edytorskiej należy się więc ukłon w stronę Wydawnictwa Naukowego Katolickiego Uniwersytetu Lubelskiego Jana Pawła II.

Jerzy Bagrowicz*

\title{
Jarosław Korczak, Błażej Przybylski (red.), Różne oblicza edukacji. Instytucje i ich znaczenie edukacyjne w zmieniającym się świecie, Toruń: Adam Marszałek, 2016, s. 246.
}

DOI: http://dx.doi.org/I0.12775/PCh.2016.035

Nakładem Oficyny Wydawniczej „Adam Marszałek” ukazała się w 2016 roku wieloautorska książka pod redakcją Jarosława Korczaka i Błażeja Przybylskiego pod tytułem: Różne oblicza edukacji. Instytucje i ich znaczenie edukacyjne w zmieniajacym się świecie. Choć obaj redaktorzy są związani

* Ks. prof. zw. dr hab. Jerzy Bagrowicz jest emerytowanym profesorem pedagogiki i teologii Uniwersytetu Mikołaja Kopernika w Toruniu, założycielem i wieloletnim redaktorem czasopisma Paedagogia Christiana. Adres: ul Kościelna 8a, 87-800 Włocławek; e-mail: bagro@umk.pl. 
z naukowym środowiskiem pedagogicznym w Warszawie, to w swój projekt włączyli również pedagogów z Torunia i innych polskich ośrodków naukowych. Na recenzowaną książkę składają się kolejne rozdziały, a już przez podział jej głównych części redaktorzy przekazali czytelnikom informacje o jej treści. Trzy części publikacji są skonstruowane logicznie, by zawrzeć w schemacie wydawniczym ,płynny, zmienny czy też nieuchwytny charakter dzisiejszego świata i stosunków międzyludzkich" ". Próbę uchwycenia gwałtownie zmieniających się ,znaczeń” wybranych instytucji edukacyjnych i różnych obszarów życia społecznego należy uznać za przedsięwzięcie ciekawe zarówno w teoretycznych analizach, jak również $\mathrm{w}$ prezentacjach autorskich badań własnych.

Pierwsza część: Szkoła jako środowisko uczenia się i nauczania zawiera istotne tematy dla instytucjonalnych zmagań edukacyjnych w Polsce, będących przedmiotem kolejnych dyskusji i zmian. $Z$ jednej strony wiemy o sukcesach polskich uczniów, wysoko ocenionych w międzynarodowych sondażach $^{2}$, z drugiej mamy kolejną odsłonę reformy systemu edukacji, zapowiadaną już wcześniej przez badaczy tego zagadnienia ${ }^{3}$. Autorzy przyglądają się szkole i systemowi szkolnemu, stanowiącemu główną agendę socjalizacji, analizując różne wymiary edukacji formalnej. Oblicza kultury szkoły ukazują instytucje szkolne jako wytwór specyficznej kultury, a typologia szkolnych kultur jest ciekawa poznawczo i pozwala lepiej rozumieć klimaty, jakie panują w szkole. Autorzy opisują różne typy szkolnych kultur, spoglądając na szkołę jako na wytwór specyficznej kultury. Interesujący poznawczo jest rozdział opisujący różne „fronty” szkolnych wojen, ukazujący zarzewia konfliktów w szkole tradycyjnej wobec tej nowoczesnej, a także na frontach widzianych od strony nauczycielskiej i uczniowskiej. Przybliżenie różnych frontów szkolnych wojen realistycznie przedstawia rzeczywistość edukacyjną w naszym kraju. Bardzo ważnym głosem dyskusji w zmieniającym się świecie jest pytanie o to, jak szkoła „radzi sobie” (czy raczej nie radzi!) z cielesnością ucznia, słusznie nazywające podejmowane działania pedagogiczną zdradą ciała w rytuałach szkolnych, gdyż instytucje eduka-

${ }^{1}$ Różne oblicza edukacji. Instytucje $i$ ich znaczenie edukacyjne $w$ zmieniajacym się świecie, red. Jarosław Korczak, Błażej Przybylski (Toruń: Adam Marszałek, 2016), 5.

${ }^{2}$ Krzysztof Domaradzki, „Polska ma jeden z najlepszych systemów edukacji na świecie”, w: http://kariera.forbes.pl/polska-ma-jeden-z-najlepszych-systemow-edukacji-na-swiecie,artykuly,176211,1,1.html (dostęp: październik 2016).

${ }_{3}$ Por. Aleksander Nalaskowski, Pedagogiczne zwierzatko. Fenomen niewiedzy (Kraków: Wydawnictwo Impuls, 2015). 
cyjne posiadają propozycje edukacyjne dla umysłu, pomijając przy tym zupełnie ciało i związane z nim problemy. Istotnym w tej części głosem jest wypowiedź dotycząca edukacji medialnej w zmieniającej się rzeczywistości, z konkretnymi wskazaniami do właściwego wykorzystania nowych mediów i ostrzeżeniami przed ich nadużywaniem przez uczniów. Ciekawym poznawczo głosem jest analiza programów wyborczych najważniejszych sił politycznych w Polsce autorstwa Błażeja Przybylskiego, który przedstawia i analizuje różne propozycje dotyczące szkoły czy systemu szkolnictwa. Dzięki temu głosowi lepiej dostrzegamy, jak ważna jest szkoła i system edukacji w programach partyjnych oraz w strategiach sprawowania władzy, co wydaje się szczególnie aktualne wobec toczących się w naszym kraju gorących debat o kolejnej reformie edukacji ${ }^{4}$.

Zbiór autorskich głosów recenzowanej publikacji w części: Instytucje pozaszkolne $i$ ich wymiar edukacyjny, zawiera warte zauważenia, przedstawione rzeczowo analizy ukazujące znaczenie rodziny dla procesu kształtowania tożsamości jednostki i potrzebę kształtowania autentycznej i autonomicznej tożsamości w tej podstawowej komórce społecznej. Także ukazany w sposób systematyczny i oparty na solidnych źródłach i badaniach edukacyjny wymiar działalności Kościoła katolickiego ukazuje spójny system edukacyjny (kształcenia i wychowania) zmierzający do całościowej formacji człowieka, co potwierdzają inne publikacje z tego obszarus. Uczenie się $\mathrm{w}$ miejscu pracy oraz przedstawienie edukacyjnej roli zakładu pracy w zmieniającym się świecie wskazało kierunek tworzenia modelu organizacji uczącej się. Ważnym głosem tej części publikacji jest prezentacja procesu wychowania w przestrzeni mediów, wskazująca na strategie, których przyjęcie przez rodziny może uchronić młodych przed uzależnieniem i negatywnymi skutkami mediów masowych. Kończąca tę część recenzowanej pracy prezentacja najważniejszych dokonań Tony'ego Blaira w zakresie szkolnictwa w Wielkiej Brytanii w latach 1997-2001 pokazuje znaczenie osób sprawujących władzę dla kształtu procesów edukacyjnych oraz omawia szereg konkretnych działań podejmowanych przez ekipę rządzącą w UK, zmieniających sam system szkolny w tym kraju. Ten głos wydaje się ważny dla pol-

${ }^{4}$ Por. Piotr Czartoryski-Sziler, „Nasz wywiad: Prof. Nalaskowski o protestach ZNP”, http://wpolityce.pl/polityka/311417-prof-nalaskowski-o-protestach-znp-wpisuje-sie-to-w-jakis-wielki-ogolnonarodowy-kod-nad-ktorym-patronat-ma-jakis-zbiorowy-kijowski-nasz-wywiad? (dostęp: październik 2016).

${ }_{5}^{5}$ Por. Edukacyjny potencjat religii, red. Jerzy Bagrowicz, Jarosław Horowski (Toruń: Wydawnictwo UMK, 2012). 
skich pedagogów w kontekście powrotu polskich rodzin z Wielkiej Brytanii, a ciągle niewielka jest wiedza na temat różnic w systemach edukacyjnych i wyzwań związanych z sektarianizmem i uprzedzeniami klasowymi obecnymi na Wyspach Brytyjskich ${ }^{6}$.

Ostatnią część recenzowanej publikacji stanowią raporty z badań własnych wielu autorów, przedstawiające rolę instytucji edukacyjnych w procesie socjalizacji w Polsce. Tę część rozpoczyna prezentacja wyników badań nad znaczeniem doświadczeń życiowych dla konstruowania tożsamości zawodowej studentów pedagogiki i pracy socjalnej, która stanowi dobry przyczynek do pogłębionej dyskusji na temat obecnej kondycji kształcenia akademickiego i nowych wyzwań edukacyjnych ${ }^{7}$. Dalszy ciąg tej dyskusji jest możliwy dzięki prezentacji badań planów zawodowych studentów II roku studiów uzupełniających z warszawskich uczelni wyższych - technicznych i humanistycznych. Przedstawienie uwarunkowań rynkowych, ekonomicznych i społecznych, kształtujących plany życiowe i zawodowe studentów, to cenny wynik wspomnianych badań. Także prowokujące do refleksji są wyniki badań internetowych dotyczących procesu inflacji dyplomów jako konsekwencji ukrytego programu edukacyjnego, zatytułowane „Młodzi - (nie) wykształceni?". Analiza praktycznych umiejętności (a niekiedy ich braku) absolwentów uczelni pedagogicznych jest treścią badań ukazujących przygotowanie nauczycieli szkół gimnazjalnych do pracy z uczniami zagrożonymi uzależnieniami. Ważnym wnioskiem $\mathrm{z}$ tego badania jest zauważenie występowania dysproporcji w dostępie do wiedzy na temat uzależnień i profilaktyki w środowisku nauczycielskim.

Po uważnej lekturze dzieła należy stwierdzić, iż redaktorzy i autorzy publikacji: Różne oblicza edukacji. Instytucje i ich znaczenie edukacyjne w zmieniajacym się świecie, wnoszą nowe treści do dyskursu pedagogicznego, a książka daje kilka ważnych odpowiedzi na obecne w przestrzeni edukacyjnej pytania. Odkrywając problemy, przed którymi stoi współczesna młodzież uczestnicząca w edukacji formalnej i żyjąca w rodzinach czy społecznościach lokalnych, twórcy tej publikacji przedstawili różnorodność działań edukacyjnych, będących odpowiedzią na owe problemy w zmieniającej się dynamicznie rzeczywistości społecznej. Innowacyjne są szczególnie badania własne zaprezentowane przez autorów, ale także większość z cyklu po-

${ }^{6}$ Por. Marcin Motyka, „«Sektarianizm» zagrożeniem systemu edukacyjnego w świetle doświadczeń ze Szkocji”, Wychowanie Na Co Dzień 1 (2015):7-12.

${ }^{7}$ Por. Piotr Krakowiak, Kliniczna praca socjalna narzędziem wspierania osób u kresu zycia i ich rodzin (w druku). 
dejmowanych tematów, nieobecnych w innych publikacjach z obszaru nauk społecznych. Przemiany systemowe i polityczne uwarunkowania edukacyjnych reform nadal są ważną częścią naszego życia społecznego i rozwoju nauk o wychowaniu w naszym kraju. Zmiany zaproponowane w polskim systemie edukacyjnym już po wydaniu tej książki w 2016 roku wskazują na ciągłą dynamikę przemian i związanych z nimi wyzwań dla pedagogów, uczniów i całego społeczeństwa, trudnych do przewidzenia przez autorów analiz polskiej edukacji i jej wyzwań sprzed zaledwie kilku lat ${ }^{8}$.

Piotr Krakowiak*

\section{Bibliografia}

Edukacyjny potencjat religii, red. Jerzy Bagrowicz, Jarosław Horowski. Toruń: Wydawnictwo UMK, 2012.

Motyka, Marcin. „«Sektarianizm» zagrożeniem systemu edukacyjnego w świetle doświadczeń ze Szkocji”. Wychowanie Na Co Dzień 1 (2015): 7-12.

Nalaskowski, Aleksander. Pedagogiczne zwierzatko. Fenomen niewiedzy. Kraków: Wydawnictwo Impuls, 2015.

Różne oblicza edukacji. Instytucje i ich znaczenie edukacyjne w zmieniającym się świecie, red. Jarosław Korczak, Błażej Przybylski. Toruń: Adam Marszałek, 2016.

\section{Ewa Ogrodzka-Mazur, Grzegorz Błahut, Teresa Bogusława Chmiel (red.), Wspótczesne ojcostwo. Konteksty kulturowe, peda- gogiczne i prawne, Toruń: Dolnośląska Szkoła Wyższa (Cieszyn), Wydawnictwo Adam Marszałek, 2016, s. 201.}

DOI: http://dx.doi.org/10.12775/PCh.2016.036

Zagadnienia składające się na treść omawianej publikacji zostały zawarte w trzech częściach. 1) Społeczno-kulturowe aspekty ojcostwa. W poszuki-

${ }^{8}$ Por. Witold Kołodziejczyk, Marcin Polak, „Jak będzie zmieniać się edukacja? Wyzwania dla polskiej szkoły i uczniów”, http://www.instytutobywatelski.pl/wp-content/uploads/2011/11/edukacja_kolodziejczyk-polak_internet.pdf (dostęp: październik 2016).

* Ks. dr hab. Piotr Krakowiak jest kierownikiem Katedry Pracy Socjalnej na Wydziale Nauk Pedagogicznych Uniwersytetu Mikołaja Kopernika w Toruniu. Adres: Wydział Nauk Pedagogicznych UMK, ul. Lwowska 1,87-100 Toruń; e-mail: pkrakow@umk.pl. 